\title{
ВЗАИМОДЕЙСТВИЕ СЕМЬИ И ДЕТСКОГО САДА В ВОПРОСАХ ФИЗИЧЕСКОГО ВОСПИТАНИЯ ДОШКОЛЬНИКОВ ${ }^{1}$
}

\section{INTERACTION OF THE FAMILY AND KINDERGARTEN IN THE ISSUES OF PHYSICAL EDUCATION OF PRESCHOOLERS}

\section{E. Kirkina \\ N. Shchemerova \\ N. Hrykina}

Summary: The article discusses the features of the interaction of the family and kindergarten in the issues of physical education of preschoolers. The main types of activities for the physical development of preschool children are presented. The forms of mutual cooperation of pedagogs and parents in the process of physical education of preschoolers are described.

Keywords: preschool education, physical development, physical education, family education.
Киркина Елена Николаевна

к.филол.н., дочент, ФГБОУ ВО «Мордовский государственный педагогический университет им. М.Е. Евсевьева», г. Саранск kirkinaelena@yandex.ru

Щемерова Надежда Николаевна

к.филол.н., дочент, ФГБОУ ВО «Мордовский государственный педагогический университет им. М.Е. Евсевьева», г. Саранск nadya.shem@mail.ru

Хрюкина Надежда Андреевна ФГБОУ ВО «Мордовский государственный педагогический университет им. М.Е. Евсевьева», г. Саранск nadezhdahriukina@yandex.ru

Аннотация: В статье рассматриваются особенности взаимодействия семьи и детского сада в вопросах физического воспитания дошкольников. Представлены основные виды деятельности по физическому развитию детей дошкольного возраста. Описываются формы взаимного сотрудничества педагогов и родителей в процессе физического воспитания дошкольников.

Ключевые слова: дошкольное образование, физическое развитие, физическое воспитание, семейное воспитание.

Принципы воспитания, которыми должен руководствоваться будущий педагог в процессе своей деятельности, довольно широко рассматриваются на занятиях в процессе обучения. Это один из самых важных вопросов, стоящих перед педагогами. Также важно научиться применять полученные знания, полученные в вузе или изученные самостоятельно на практике. В настоящей статье вопросы физического воспитания дошкольников в рамках темы взаимодействия семьи и детского сада рассматриваются через призму принципа единства воспитательного воздействия. Данный принцип в физическом воспитания дошкольников является основополагающим, т.к. если физическим развитием детей будут заниматься родители и педагоги детского сада, но во всей их работе не будет единых целей и задач, то и результат окажется соответствующим.

Семья и детский сад считаются теми социальными группам, где ребёнок получает определённый уровень здоровья. Они должны работать сообща, чтобы не навредить организму дошкольника, как с физической стороны, так и психологической. Происходят ситуации, когда

Исследование выполнено в рамках гранта на проведение научно-исследовательских работ по приоритетным направлениям научной деятельности вузов-партнеров по сетевому взаимодействию (УлГПУ и МГПИ) по теме «Подготовка будущих педагогов дошкольного образования к работе по физическому воспитанию дошкольников». 
из-за неосведомлённости родителей у детей появляются проблемы, например, искривление позвоночника и т.п., то роль «корректора» играют специалисты дошкольного учреждения. И для того, чтобы полноценно организовать среду, в воспитательном процессе необходимы доверительные отношения между семьёй и детским садом. Без активного участия родителей, прежде всего в физическом воспитании своего ребенка, невозможно создать разносторонне развитую личность [3].

Педагоги и администрация в свою очередь должны контролировать, проводить разнообразные семинары, мастер-классы, продумывать разнообразные мероприятия, посвященные физическому воспитанию, учитывая возрастные и индивидуальные особенности детей.

Традиционно систематическая работа по физическому воспитанию и развитию детей дошкольного возраста включает оздоровительное, воспитательное и образовательное направления, которые осуществляются в едином процессе [2].

Анализ действующих комплексных программ обучения и воспитания и парциальных программ физического воспитания показал, что в дошкольных учреждениях рекомендуется постоянно совершенствовать психофизические качества, формировать у детей здоровый образ жизни. Для этого необходимо использовать различные формы работы, которые предусматривают постепенное овладение детьми знаниями, умениями и навыками, необходимых для здорового образа жизни, физического развития.

Хорошим подспорьем в работе с родителями по физическому воспитанию и формированию здорового образа жизни может стать метод проектов. Основными задачами проектов являются:

- разработка педагогом и родителями совместного проекта;

- повышение профессиональной культуры педагогов в вопросах здоровьесбережения;

- разработка и апробация системы физкультурнооздоровительной работы;

- взаимодействие в работе с родителями по вопросам физического развития, охраны жизни и здо-

\section{ровья детей.}

В процессе взаимодействия семьи и детского сада в вопросах физического воспитания дошкольников необходимо широко использовать в практике нетрадиционные методы и средства оздоровления детей: дыхательную гимнастику, упражнения на расслабление, игровые упражнения для глаз, массаж. С целью ознакомления родителей с нетрадиционными методами и средствами оздоровления детей проводятся родительские собрания, на которые привлекаются физкультурные и медицинские работники, беседы, консультации, конкурсы, совместные мероприятия.

Так как работа по физическому воспитанию дошкольников должна включать эмоционально-мотивационный компонент, рекомендуется особое внимание уделять проведению совместных с родителями спортивных праздников и развлечений, которые, являясь формой активного отдыха, способствуют проявлению у ребенка и родителей положительных эмоций, приобщают к физической культуре и спорту [1]. Хорошо организованные, содержательные физкультурные досуги и праздники, в ходе которых ребенок приобретает специальные навыки, оказывают положительное воздействие на общее развитие, способствуют наиболее успешному участию в этой деятельности. Включение в содержание физкультурных досугов и праздников сведений о гигиене, строении человеческого организма, различных способах закаливания, о спорте, целенаправленное формирование мотивации вести здоровый образ жизни, активное участие воспитателей и родителей в спортивных праздниках и развлечениях, а также личный пример взрослых заботы о своем здоровье разносторонне решает задачи физического воспитания дошкольников

Таким образом, взаимодействие семьи и детского сада в вопросах физического воспитания дошкольников, основанное на принципе единства воспитательного воздействия является основой решения задач физического воспитания: охраны жизни, укрепления и сохранения здоровья, закаливания, развития двигательных способностей, формирования бережного отношения к своему организму.

\section{ЛИТЕРАТУРА}

1. Доронова Т.Н. Взаимодействие дошкольного учреждения с родителями. Пособие для работников дошкольных образовательных учреждений. М., 2002. $120 \mathrm{c.}$

2. Меренков А.В. Родители и педагоги: растим ребенка вместе / А.В. Меренков. — Екатеринбург: Изд-во Дома учителя, 2005. - 143 с.

3. Прищепа С.С., Шатверян Т.С. «Сотрудничество ДОУ и семьи в физическом воспитании детей раннего и дошкольного возраста». - ТЦ «Сфера», М.: 2013

4. Сухомлинский В.А. Избранные педагогические сочинения в 3 т., т. 1, с. 167

( Киркина Елена Николаевна (kirkinaelena@yandex.ru), Щемерова Надежда Николаевна (nadya.shem@mail.ru)., Хрюкина Надежда Андреевна (nadezhdahriukina@yandex.ru)

Журнал «Современная наука: актуальные проблемы теории и практики» 